\title{
Tamburlaine: Christopher Marlowes fremder Held
}

\author{
Ralf Hertel
}

Er ist ein edler Wilder, „a noble savage“, und „Herculean Hero“ (Eugene M. Waith), zugleich aber auch ein „diabolical [...] Atheist“ (Robert Greene), „a machine [...] that produces violence and death" (Stephen Greenblatt) oder gar eine Massenvernichtungswaffe, „a weapon of mass destruction“, verantwortlich für das, was Richard Wilson einen „Marlovian holocaust" nennt. ${ }^{1}$ Wie immer man ihn sehen mag: Christopher Marlowes Tamburlaine lässt, bis hin zu gegenwärtigen Interpreten, niemanden unberührt. In einer beispiellosen Gewaltorgie steigt dieser skythische Schäfer zum Herrscher über ganz Asien auf - da splittern Schädel, da werden Jungfrauen aufgespießt und besiegte Könige Pferden gleich vor Wagen gespannt und $\mathrm{zu}$ Tode geschunden. In ihrer Heterogenität weisen die Zitate Marlowes Tamburlaine als eine besonders schillernde Bühnenfigur aus, eine Figur, die gleichermaßen Abscheu und Bewunderung hervorruft, die fremd ist und doch fasziniert.

Im Folgenden möchte ich zeigen, dass es gerade das Schillernde ist, das Tamburlaine interessant macht - das, was das Publikum oszillieren lässt zwischen Furcht und Faszination. Und, trotz aller Grausamkeit, zu einem Helden; zu einem Helden, der spezifisch elisabethanische Ängste und Ambitionen reflektiert. Der Sonderforschungsbereich „Helden - Heroisierungen - Heroismen“, in dessen Kontext die Beiträge zu dieser Publikation entstanden sind, hat sich erklärterweise zum Ziel gesetzt, Helden „als personale Verdichtungen gesellschaftlicher Wertordnungen und Normengefüge" zu untersuchen. ${ }^{2}$ Ich denke, dass Marlowes Tamburlaine ein hervorragendes Beispiel für eine solche „personale Verdichtung“ darstellt. Seine schillernde Widersprüchlichkeit entspricht - und verdichtet - jene des englischen Selbstverständnisses im späten 16. Jahrhundert, das zwischen imperialem Anspruch und Minderwertigkeitskomplex changiert.

1 Robert Greene wird zitiert in John Russell Brown (Hg.): Marlowe: Tamburlaine the Great, Edward the Second and The Jew of Malta. A Casebook. Houndmills [u.a.] 1994, 24. Stephen J. Greenblatt: Marlowe and Renaissance Self-Fashioning. In: John Russell Brown (Hg.): Marlowe. Tamburlaine the Great, Edward the Second and The Jew of Malta. A Casebook. Houndmills [u.a.] 1994, 207-229, hier 209. Eugene M. Waith: Marlowe's Herculean Hero. Nachgedruckt in John Russell Brown (Hg.): Marlowe. Tamburlaine the Great, Edward the Second and The Jere of Malta. A Casebook. Houndmills [u.a.] 1994, 87-112, hier 87, 89. Richard Wilson: Visible Bullets. Tamburlaine the Great and Ivan the Terrible. In: Richard Wilson (Hg.): Christopher Marlowe. Harlowe [u.a.] 1999, 120-139, hier 129.

2 Ralf von den Hoff [et al.]: Helden - Heroisierungen - Heroismen. Transformationen und Konjunkturen von der Antike bis zur Moderne. Konzeptionelle Ausgangspunkte des Sonderforschungsbereichs 948. In: helden. heroes. héros. 1: 1, 2013, 7-14, hier 8, DOI 10.6094/helden. heroes.heros/2013/01/03. 


\section{Der fremde Tamburlaine}

Tamburlaines Fremdheit ist offensichtlich. Als Skythe ist er Marlowes Publikum schon ethnisch und geografisch fern. Als Schäfer, der auf brutale Weise zum Herrscher über ganz Asien aufsteigt, stellt er zudem alle sozialen Hierarchien infrage ein Aufstieg wie der seine musste selbst in einer Zeit wachsender sozialer Mobilität, wie sie die elisabethanische darstellt, die Vorstellungskraft sprengen. Schließlich ist der historische Tamburlaine - oder Tamerlan, oder Timur der Lahme - als Muslim Marlowes Publikum auch religiös fremd. Und wenn Marlowe ihn den Koran auf offener Bühne verbrennen lässt, dann ist das nicht Ausdruck einer Hinwendung zum Christentum, sondern vielmehr eine megalomane Herausforderung aller Gottheiten. Marlowe „[is] daring God out of heaven with that Atheist Tamburlaine“, wie schon Marlowes Zeitgenosse Robert Greene erkennt. In Tamburlaine, der neben sich keine höheren Mächte gelten lassen will, deutet sich ein Atheismus an, der Marlowes Publikum kaum weniger fremd gewesen sein mag als der Islam. ${ }^{3}$ Vor allem aber ist es seine grundlose Grausamkeit, die Tamburlaine so fremd erscheinen lässt. Es scheint ihn ein Zorn, eine Wut zu treiben, die sich weder beschwichtigen noch erklären lässt. Selbst die Bitten seiner Frau (um die er gerade noch so eindringlich geworben hat), ihre Heimatstadt Damaskus zu verschonen, bleiben unerhört. Stattdessen statuiert er an Jungfrauen, die um Gnade für die Stadt flehen, ein Exempel und lässt sie an den Stadtmauern aufknüpfen.

Zutiefst verstörend ist Tamburlaine auch in seiner Anlage als Bühnenfigur. Marlowes Drama kennt nur eine Bewegung: den unaufhaltsamen Aufstieg des Protagonisten. Der militärische Anführer Theridamas, der persische König, der osmanische Herrscher Bajazeth, Callapine als Anführer einer panasiatischen Heerschar immer mächtigere Gegner fordern Tamburlaine heraus, nur um von diesem als Fußschemel erniedrigt, in Käfigen ausgestellt oder als vor seinen Wagen gespannte und gestriegelte Sklaven zu Tode geschunden zu werden. Nichts kann Tamburlaine aufhalten, nichts seiner Brutalität und Hybris Einhalt gebieten. Dabei lehrt doch das elisabethanische Drama, dass jedem Aufstieg ein Fall folgt, dass das Rad der Fortuna sich beständig dreht. Selbst Shakespeares vielleicht gerissenster Schurke, Richard III., der in seinem unbedingten Machtwillen Tamburlaine durchaus ähnelt, kommt nach seinem blutigen Aufstieg doch zu Fall.

Allein für Tamburlaine scheint dieses Gesetz vom dem Aufstieg folgenden Fall nicht zu gelten. Warum sollte es auch? Warum sollte sich Tamburlaine, den keine Macht auf Erden und keine im Himmel halten kann, ausgerechnet den Gesetzen dramatischer Genres beugen? Und wenn Tamburlaine in der wegen des großen Erfolges nachgeschobenen Fortsetzung des Stücks doch noch den Tod findet, so irritiert selbst dieses Ende. Tamburlaine findet seinen Meister nicht in einer stärkeren oder gar christlichen Armee. Sein Tod lässt sich noch nicht einmal als göttliche

3 Zitiert in Brown: Marlowe (Anm. 1), 23. 
Vergeltung deuten. Er folgt unmittelbar auf seine Verbrennung des Korans und seine Herausforderung Mohameds. Wie fremd aber muss einem elisabethanischen Publikum der Gedanke gewesen sein, allein ein islamischer Gott habe die Macht, Tamburlaine aufzuhalten? Kurz: Tamburlaine hätte Marlowes Publikum fremder nicht sein können. Soziale Ordnungen, den Glauben an Gott, fundamentale Regeln der Menschlichkeit - all das setzt Tamburlaine außer Kraft. Gerade darin scheint seine Bestimmung zu liegen: alles zu verneinen, an das sein Publikum glauben mag. Tamburlaine ist, mit den Worten Tobias Dörings, eine ikonoklastische Figur, die sich gerade durch die Auslöschung aller Werte und Normen definiert. $^{4}$

\section{Der fremde Tamburlaine?}

Und doch: Bei genauerer Betrachtung stellt man fest, dass Tamburlaine vielleicht doch nicht ganz so fremd ist, wie er auf den ersten Blick erscheint. Für Döring beispielsweise ist er nicht allein negativ konnotiert; in seiner Lesart wird Tamburlaine als proto-protestantischer Ikonoklast zu einem „Helden der Auslöschung“, der seinem Publikum hilft, die „Gründungsgewalt [der] protestantischen Staatskirche“ zu verarbeiten, „die Gewalt des Bildersturms, des vorsätzlichen Bruchs mit etablierten Formen, Ritualen und Gestaltungen des Heiligen im kulturellen Gedächtnis“. ${ }^{5}$ Andere, wie Leah S. Marcus, sehen in Tamburlaine eine betont männlich-kriegerische Figur, die zur Projektionsfläche einer frustrierten Elite wird, die unter der zögerlichen Königin Elisabeth kaum Möglichkeiten findet, sich militärisch auszuzeichnen. Marcus liest das Drama denn auch als ein Stück, das sich gegen eine spätelisabethanische „effeminacy“ richtet und letzthin gegen Elisabeth selbst. ${ }^{6}$

In der Tat gibt es immer wieder Momente, in denen Tamburlaines Fremdheit in unerwartete Annäherung umschlägt. So überrascht seine Vision der Weltherrschaft dadurch, dass sie die Befreiung christlicher Gefangener aus osmanischen Galeeren prominent beinhaltet (I 3, 3, 44). Und wenn Marlowe mit Tamburlaine einen Muslim den Koran verbrennen lässt, dann lässt sich das möglicherweise auch verstehen als die Inszenierung der Hoffnung auf eine Eindämmung des gerade im 16. Jahrhundert als Bedrohung verstandenen Islam. „Now will the Christian miscreants be glad, | Ringing with joy their superstitious bells | And making bonfires for my overthrow" (I 3, 3, 236-238): Dem besiegten Türkenherrscher Ba-

4 Tobias Döring: Helden der Auslöschung: Zum Gedenken an Ikonoklasten. In: Achim Aurnhammer und Manfred Pfister (Hg.): Heroen und Heroisierungen in der Renaissance (Wolfenbütteler Abhandlungen zur Renaissanceforschung; 28). Wiesbaden 2013, 147-164, hier 156.

5 Ebd., 154.

6 Leah S. Marcus: Epilogue: Marlowe in tempore belli. In: Sara Munson Deats [et al.] (Hg.): War and Words. Horror and Heroism in the Literature of Warfare. Lanham, MD 2004, 295-316, hier 305. 
jazeth legt Marlowe hier Worte in den Mund, die Tamburlaine nachgerade zum Retter des christlichen Europa stilisieren. ${ }^{7}$

Tamburlaine offenbart eine überraschende Nähe nicht nur allgemein zum christlichen Europa, sondern auch spezifischer zum elisabethanischen England. Insbesondere gibt es erstaunliche Überschneidungen zwischen Tamburlaines Expansionsdrang und den unter Elisabeth erwachenden imperialen Wunschvorstellungen. ${ }^{8}$ So verspricht Tamburlaine etwa, das Mittelmeer von nordafrikanischen Piraten zu säubern. Dabei sind es eben jene "cruel pirates of Argiers“ (I 3, 3, 55), die im Mittelmeer die größte Bedrohung für Englands Aufstieg darstellen. Außerdem vermisst das Drama genau jene Regionen, in welche die frisch gegründeten Levant Company und Muscovite Company streben. Balsera, Aleppo, Babylon die Ziele von Tamburlaines Machtstreben sind jene Orte, die für Englands Aufstieg zur Weltmacht von größter Bedeutung sind. Mit anderen Worten: Tamburlaines geografische Ambitionen sind diejenigen Englands, und seine Eroberungen nehmen vorweg, wovon die Elisabethaner nur träumen können.

Schließlich führt Tamburlaine auch die Strategie vor, mit welcher der englische Aufstieg zu erreichen wäre, nämlich Emulation. Tamburlaine lernt schnell, insbesondere vom osmanischen Herrscher Bajazeth, dessen Epitheton als „Geißel Gottes“ (I 3, 3, 44) er schnell für sich reklamiert. Der militärischen Schlacht gegen den Osmanen geht eine verbale voraus, die Tamburlaines Strategie der Emulation besonders eindrucksvoll vorführt. Adressiert Bajazeth zunächst seine Gefolgsleute, weil er Tamburlaine einer direkten Anrede für unwürdig erachtet, so tut es ihm Tamburlaine postwendend nach. Empört Bajazeth sich darüber, von Tamburlaine mit seinem Namen angesprochen zu werden („And dar'st thou bluntly call me Bajazeth?“ [I 3, 3, 71]), so imitiert Tamburlaine ihn wortwörtlich („And dar'st thou bluntly call me Tamburlaine?" [I 3, 3, 74]). Schwört der Osmane beim Koran, Tamburlaine zu vernichten, so schwört Tamburlaine umgehend ebenfalls allerdings auf sein eigenes Schwert, was bezeichnend ist für den „atheist Tamburlaine“.

Möglicherweise war Marlowes Publikum Tamburlaines Strategie der Emulation des Osmanen gar nicht so fremd. Zeitgenössische Publikationen wie Richard Knolles' Generall Historie of the Turkes von 1603 zeigen, dass man das Osmanische Reich zwar als Bedrohung, zugleich aber auch als mögliches Vorbild ansah, genauer gesagt als Vorwegnahme jenes Imperiums, das England erst zu werden hoffte. Bereits der erste Satz von Knolles' Geschichte der Türken verrät diese ambiva-

7 Ich zitiere Marlowes Dramen Tamburlaine the Great Part I und Tamburlaine the Great Part II nach der Ausgabe von David Bevington und Eric Rasmussen (Oxford 1998).

8 Vgl. Emily C. Bartels: The Double Vision of the East. Imperialist Self-Construction in Marlowe's Tamburlaine, Part One. In: Renaissance Drama 23, 1992, 3-24. Siehe auch Ralf Hertel: Bragging Turks and Winning Words. Solo-Performances in Anglo-Ottoman Encounters - The Case of Christopher Marlowe's Tamburlaine the Great. In: Ute Berns (Hg.): Solo-Performances. Staging the Early Modern Self in England. Amsterdam [u.a.] 2010, 249-268. Der vorliegende Aufsatz baut in Teilen auf diesem Essay auf. 
lente Perspektive auf die Osmanen, diese „double vision“, wie es Emily Bartels nennt. Das Osmanische Reich ist nach Knolles „the glorious Empire of the Turkes“, aber zugleich „the present terrour of the world“. 9

Tamburlaines Emulation Bajazeths spiegelt diesen englischen Blick. So wie Tamburlaine auf den osmanischen Herrscher schaut, nimmt England das Osmanische Reich wahr: als einen Gegenspieler, der zwar in vielerlei Hinsicht sehr fremd erscheint, von dem sich aber möglicherweise auch lernen lässt. In der Darstellung des Aufstiegs Tamburlaines und seiner Unterwerfung des Osmanen suggeriert Marlowes Drama, dass diese Strategie der Emulation Erfolg hat. Genauer noch: Was es vom Osmanen zu imitieren gilt und zu lernen gibt, ist vor allem Rhetorik und Selbstdarstellung. In der Schlacht selbst entlarvt Tamburlaine den Osmanen dann schnell als pompösen Schwätzer, der seinen bombastischen Worten keine Taten folgen lassen kann: „Tush, Turks are full of brags | And menace more than they can well perform" (I 3, 3, 3-4). Der pompöse, großspurige Osmane, dessen Macht nur Schein ist, ist jedoch ein Stereotyp, mit dem die Elisabethaner oftmals ihre eigene Unterlegenheit zu überdecken suchen. Anders gesagt: Marlowes Tamburlaine verifiziert eine elisabethanische Strategie der Selbstermächtigung.

So ist Tamburlaine nicht nur eine Figur des Anderen, nicht nur ,Other, sondern auch ,brother'. Es mag deshalb kein Zufall sein, dass er bei Marlowe nicht sehr asiatisch oder fremd aussieht. Geradezu englisch erscheint er hier, wird beschrieben als „pale of complexion“ (I 2, 1, 19), mit dunkelblonden Locken und Fingern, die „snowy“ (I 2, 1, 27) erscheinen. ${ }^{10}$ Auch das Titelblatt der gedruckten Ausgabe lässt diese überraschende Verwandtschaft erkennen (Abb. 1). Es zeigt uns einen Tamburlaine ganz ohne die geläufigen Insignien asiatischer Herkunft, wie wir sie bei Knolles finden (etwa den Turban, den Schnauzbart oder den Krummdolch). Vielmehr zeigt es einen lockigen, vollbärtigen Kämpfer in ritterlicher Rüstung, der wohl genauso gut ein Engländer sein könnte. Wie das Drama suggeriert die visuelle Darstellung, dass Tamburlaine den Elisabethanern, trotz seiner Fremdheit, ähnlich ist.

\section{Tamburlaine der Held}

Aber auch wenn Tamburlaine den Elisabethanern ähnlich ist, so ist er doch nicht einfach ihr Spiegelbild - vielmehr ist er ein Wunschbild, so, wie sie gerne wären. Eine gewisse Distanz bleibt erhalten, die es Marlowe erlaubt, ihn als Projektions-

9 Bartels: The Double Vision of the East (Anm. 8), 3. Richard Knolles: The Generall Historie of the Turkes, from the first beginning of that Nation to the rising of the Ottoman Familie: with all the notable expeditions of the Christian Princes against them. London 1603, 1.

10 Mit Marcus: Epilogue (Anm. 6), 300, und anders als David Bevington und Eric Rasmussen, die „snowy“ als „,sinewy“ emendieren, halte ich „snowy“, das sich in allen zeitgenössischen Ausgaben findet, nicht für einen Druckfehler. Angesichts der Tatsache, dass Marlowes Drama Tamburlaine in unterschwellige Nähe zu den Elisabethanern versetzt, scheint die ursprüngliche Formulierung durchaus passend. 


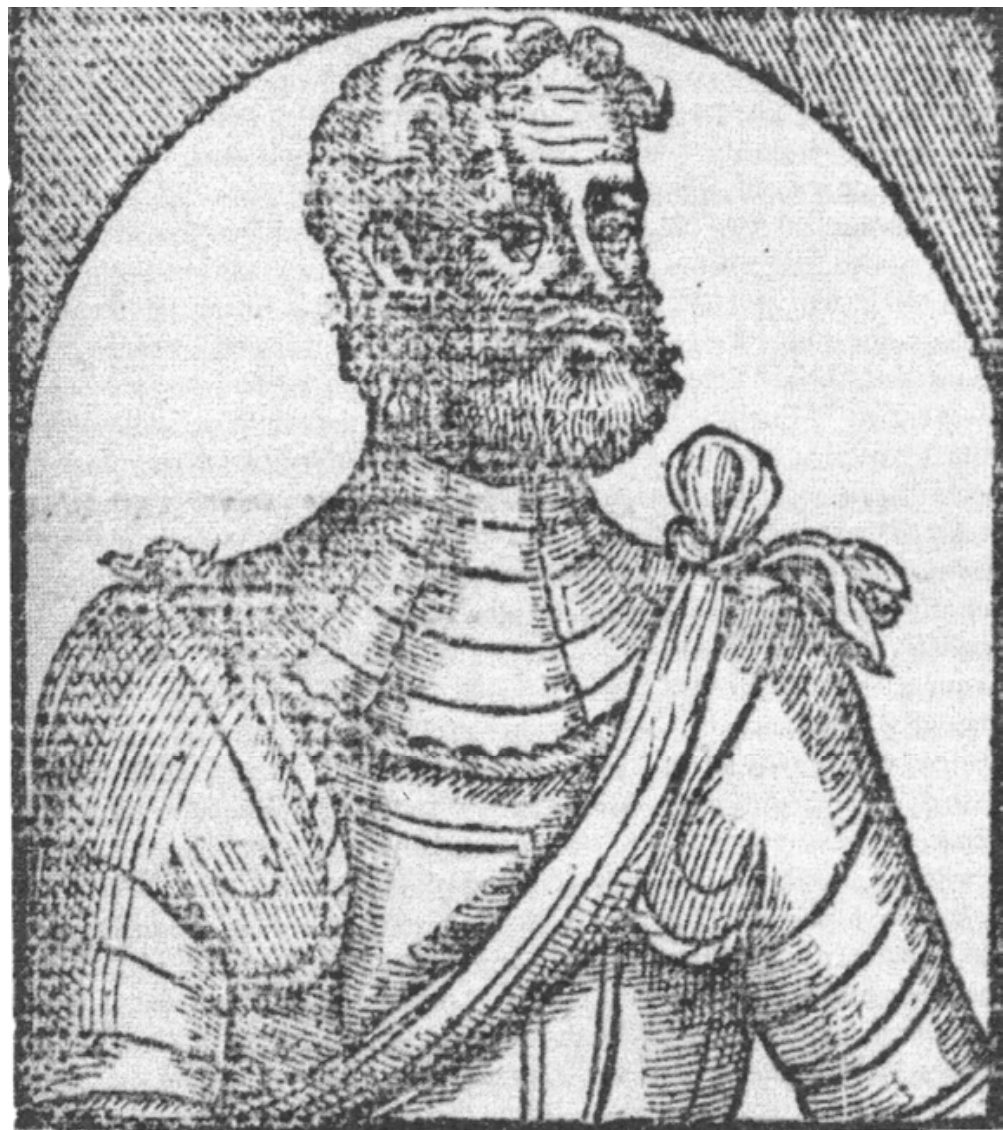

Abb. 1: Tamburlaine (Ausschnitt aus Titelblatt), Holzschnitt. In: Christopher Marlowe: Tamburlaine the Great. London 1597, San Marino, CA, Huntington Library, 12954.

figur fungieren zu lassen - als heroische Projektionsfigur, als Held, der die Macht hat, aus englischen Wunschvorstellungen Wirklichkeit werden zu lassen. Indem er die realen Kräfteverhältnisse auf den Kopf stellt, kompensiert Tamburlaine einen spezifisch elisabethanischen Minderwertigkeitskomplex. In der Realität waren die Engländer den Osmanen weit unterlegen, und zwar auf militärischer, diplomatischer und ökonomischer Ebene. Das Osmanische Reich war vielfach größer als England und erstreckte sich über drei Kontinente; England dagegen war allein schon geografisch marginal. Wenn das Osmanische Reich auch als Modell für eigene imperiale Bestrebungen herhielt, so erinnerte der Vergleich die Engländer doch auch stets daran, wie weit sie selbst noch davon entfernt waren, eine solche Weltmacht zu sein.

Es gäbe viele Beispiele, die Unterlegenheit der Engländer zu demonstrieren. Schon Knolles' Titelillustration (Abb. 2) setzt sie ins Bild in der Anordnung der englischen und osmanischen Figur. Zum Verhältnis der beiden gäbe es viel zu sa- 


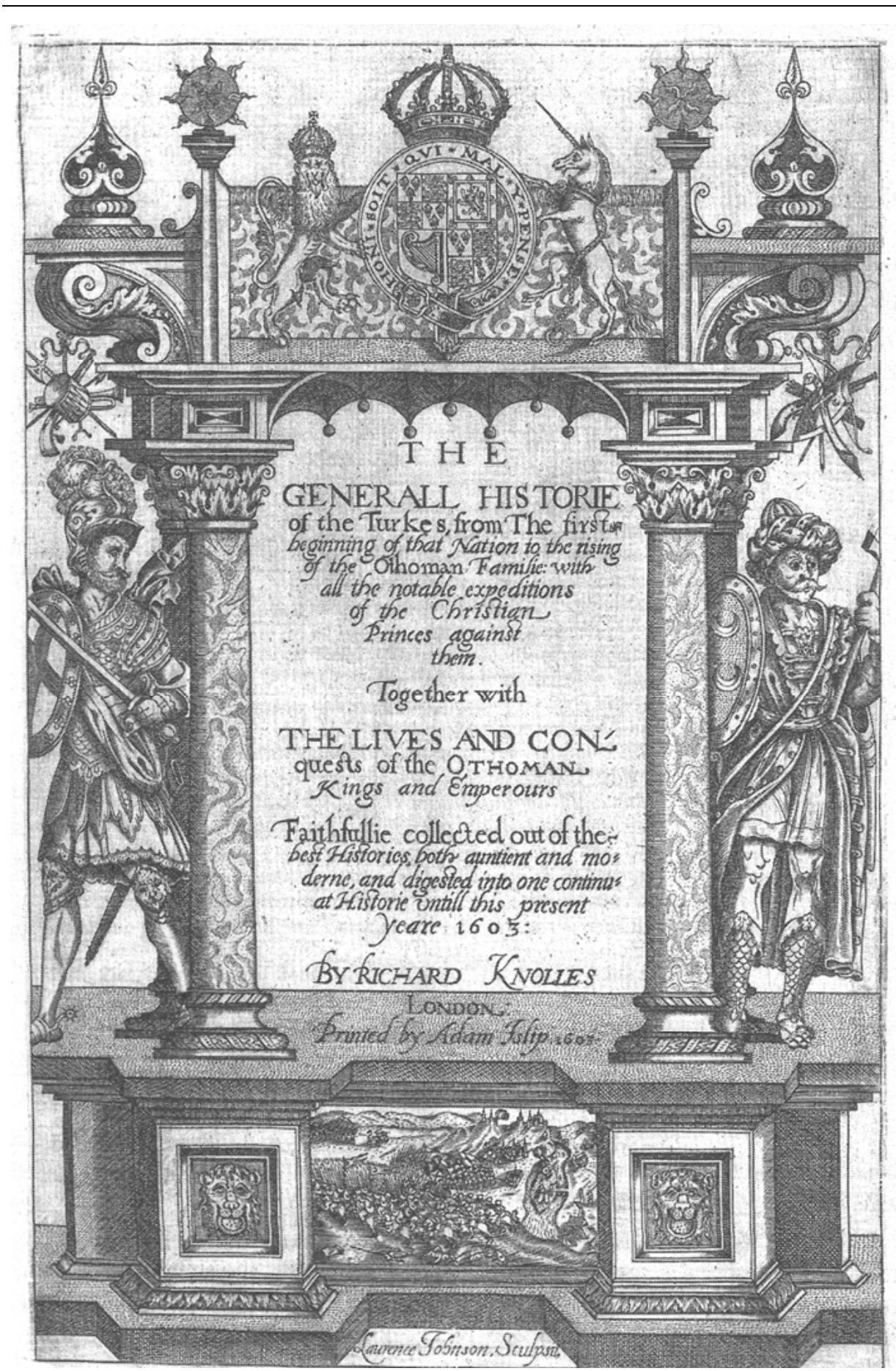

Abb. 2: Laurence Johnson: Frontispiz. In: Richard Knolles: The Generall Historie of the Turkes. London 1603, San Marino, CA, Huntington Library, 32067. 
gen, wie Richmond Barbour gezeigt hat. ${ }^{11}$ Für unseren Zweck hier reicht vielleicht schon das Offensichtlichste. Zum einen wird hier die Ambivalenz der englischen Perspektive sichtbar: Einerseits kann der gebannte Engländer - links positioniert und erkennbar durch seine Rüstung, den Bart und vor allem das Kreuz des Heiligen Georg - den Blick nicht vom Osmanen lösen. Andererseits wendet er sich in seiner Körperhaltung doch vom Osmanen ab und legt die Hand ans Schwert. Ist der Osmane hier Freund oder Feind? Kann man ihm vertrauen oder muss man sich gegen ihn wappnen? Knolles' Engländer scheint es nicht recht zu wissen. Er blickt auf den Osmanen wie Marlowes Publikum auf Tamburlaine, mit einer Mischung aus Furcht und Faszination. Vor allem aber zeigt das Bild eindrücklich die englische Unterlegenheit, denn während der Engländer ganz auf den Osmanen fixiert ist, würdigt dieser den Engländer keines Blickes. England, so die Botschaft, ist dem Osmanen gänzlich egal; er nimmt dessen Existenz noch nicht einmal wahr.

Und in der Tat, während die Engländer - anti-türkischer Propaganda zum Trotz - hofften, im Osmanischen Reich einen mächtigen Verbündeten im Kampf gegen das katholische Europa zu finden, zeigte man dort wenig Interesse an den Engländern. Aufschlussreich ist hier ein Briefwechsel zwischen Königin Elisabeth und dem osmanischen Herrscher Murad III., in dem Elisabeth vorschlägt, Handelsbeziehungen aufzunehmen. Murads Antwort ist bezeichnend, wie schon der erste Satz - hier in gekürzter Form - erkennen lässt:

We most sacred Musulmanlike Emperour, by the infinite and exceeding great power, by the everlasting and wonderful clemencie, and by the unspeakable helpe of the most mighty and most holy God, creator of all things, to be worshipped and feared with all purenesse of minde, and reverence of speech, The prince of these present times, the onely Monarch of this age, able to give scepters to the potentates of the whole world, the shadow of the divine mercy and grace, the distributer of many kingdoms, provinces, townes and cities, Prince, and most sacred Emperour of Mecca, that is to say, of Gods house, of Medina, of the most glorious and blessed Ierusalem, of the most fertile Egypt, Iemen and Iouan, Eden and Canaan, of Samos the peacable, and of Hebes, of Iabza, and Pazra, of Zeruzub and Halepia, of Caramaria and Diabekiruan, of Dulkadiria, of Babylon, and of all the three Arabias, of the Euzians and Georgians, of Cyprus the rich, and of the kingdomes of Asia, of Ozakior, of the tracts of the white and blacke Sea, of Grecia and Mesopotamia, of Africa and Goleta, of Alger, and of Tripolis in the West, of the most choise and principall Europe, of Buda and Temeswar, and of the kingdomes beyond the Alpes, and many others such like, most mightie Murad Can, the sonne of Emperor Zelim Can, which was the sonne of Zoleiman Can, which was the sonne of Zelim Can, which was the sonne of Paiizid Can, which was the sonne of Mehemed Can, \&c. We most mightie prince Murad Can, in token of our Imperiall friendship, doe signifie and declare, that now of late Elizabeth Queene of England, France and Ireland [...] sent her letters $[\ldots]$ : therefore as wee have entred into amitie, and most holy league with the most excel-

11 Siehe Richmond Barbour: Before Orientalism. London's Theatre of „the East", 1576-1626 (Cambridge Studies in Renaissance Literature and Culture; 45). Cambridge [u.a.] 2003, 19-22. 
lent kings and princes our confederates, shewing their devotion, and obedience of services towards our stately Porch (as namely the French king, the Venetians, the king of Pollonia and others) so also we have contracted an inviolable amitie, peace and league with the aforesaid Queen. ${ }^{12}$

Im Grunde sagt Murad nicht viel mehr, als dass er Elisabeth gestattet, mit ihm Handel aufzunehmen. Aber natürlich sagt der Brief zugleich sehr viel mehr aus. Er ist nicht einfach eine Antwort, er ist eine Beleidigung, welche die Engländer von höchster Stelle aus schmerzlich an die eigene Unterlegenheit erinnert. Während Murads Macht im rhetorischen Reichtum und Überfluss, seiner copia verborum, geradezu hörbar wird, während die Aufzählung seiner Titel die besten geografischen Kenntnisse und den ausdauerndsten Atem überfordert, ist Elisabeths Titel peinlich kurz.

Vor diesem Hintergrund gewinnt Tamburlaine heroische Statur als jemand, der selbst diesen Türken noch bezwingt. Werden die Engländer von den Osmanen gedemütigt, so demütigt Tamburlaine den Osmanen selbst. Er zeigt, dass selbst der Türke, „the terror of the world“ (I 3, 3, 44), terrorisiert werden kann. Anders als im Briefwechsel zwischen Elisabeth und Murad hat der Türke bei Marlowe bald nichts mehr zu sagen. ${ }^{13}$ In einer Epoche, in der englische Ambitionen immer wieder frustriert werden - erste Kolonien in der Neuen Welt scheitern, vom lukrativen Handel in Asien bleiben die Engländer ausgeschlossen, religiös und diplomatisch sind sie weitgehend isoliert - präsentiert Marlowe seinem englischen Publikum eine Figur, welcher der Aufstieg zur Weltmacht gelingt. Tamburlaine wird so zur Projektionsfläche für Machtfantasien, die einen spezifisch spät-elisabethanischen Minderwertigkeitskomplex überdecken. Er wird bei Marlowe zu jener starken Figur, welche die Engländer wohl gerne selbst abgeben würden.

Vor diesem Hintergrund ist es weniger verwunderlich, dass Tamburlaine, diese auf den ersten Blick so barbarische Figur, heroische Qualitäten gewinnt. Immer wieder wird er in heroische Nachbarschaft gerückt, in Anspielungen etwa auf griechische Sagen und deren Helden. So wurde Tamburlaine wiederholt als Herkulesfigur gelesen. ${ }^{14}$ Und Marlowe stattet seinen Protagonisten mit eben jenen Qualitäten aus, die gemeinhin dem Helden zugeschrieben werden: etwa übermenschliche Größe (in seiner Überwindung mächtigster Herrscher und seiner Herausforderung Gottes) und die Bereitschaft zur Selbstaufgabe (die er in jeder neuen Schlacht be-

12 Richard Haklyut: Principal Navigations, Voyages, Traffiques and Discoveries of the English Nation, made by Sea or overland, to the remote and farthest distant quarters of the Earth, at any time within the compasse of these 1600 yeres, Bd. 5. London 1599, 143.

13 Marlowes Drama ist dabei anachronistisch und bedient ein überkommenes Türkenklischee, das der Realpolitik Elisabeths zunehmend weniger entspricht, sucht man doch in den 1580er Jahren die Annäherung an das Osmanische Reich. Siehe Matthew Dimmock: New Turkes. Dramatizing Islam and the Ottomans in Early Modern England. Farnham [u.a.] 2005.

14 Eugene Waith: The Herculean Hero in Marlowe, Chapman, Shakespeare, and Dryden. New York und London 1967. Milena Kostic: Herculean Ambivalence in Marlowe's Tamburlaine the Great. In: Philologia 8, 2010, 71-76. 
weist). Er bedient zudem die Rolle des Retters (des christlichen Abendlands vor den Türken), und es widerfährt ihm eine nachgerade kultische Verehrung (durch Gefolgsleute, die seine Worte wie die eines Heiligen echogleich wiederholen). ${ }^{15}$

Bei Marlowe wird Tamburlaine zu einem Heros, einem „earthly god“ (II 1, 3, 138) oder Halbgott, zu einem, „for whom the powers divine have made the world“ (I 5, 1, 76). Er changiert hier zwischen Mensch und Gottheit und wird beschrieben als „man, or rather god of war" (I 5, 1, 1). Und wenn - wie etwa der Freiburger Sonderforschungsbereich betont - Heldentum nur in seiner Aufführung existiert, vor Publikum, dann wird das bei Marlowe besonders augenfällig. ${ }^{16}$ Tamburlaines Macht ist eine der Aufführung, und schon sein erster Erfolg führt das eindringlich vor Augen. Tamburlaine, Herr nur über eine kleine Räuberbande, lässt erbeutetes Gold auslegen, auf dass es in der Sonne prächtig glänze, und zieht durch seine optische und verbale Selbstinszenierung, seine „working words“ (I 2, 3, 25), den militärisch weit überlegenen Theridamas auf seine Seite. Marlowes Tamburlaine ist, mit Greenblatt, ein Held des selffashioning, einer, der sich essenzialistischen Zuschreibungen verweigert, sich nicht durch seine Geburt definieren lässt, sondern sich vielmehr selbst radikal neu entwirft. ${ }^{17}$ Das macht ihn modern und - trotz aller Grausamkeiten - faszinierend. Und schließlich macht Marlowe aus Tamburlaine, der für die Engländer bis dahin vor allem in Geschichtsbüchern existierte, eine Bühnenfigur. Das Theater aber ist das ideale Medium, um den performativen Charakter des Helden vorzuführen, um dessen mitreißende Wirkung das Publikum am eigenen Leibe spüren zu lassen. So wie Tamburlaines Gegner und seine Gefolgsleute mag auch das Publikum im Theater von Tamburlaines machtvollem Charisma, seinem Charisma der Macht, geblendet werden. So wird aus Tamburlaine nicht nur ein Held, sondern ein sehr elisabethanischer Held.

\section{Tamburlaine der fremde Held}

Und doch fehlt Tamburlaine eine Qualität des Helden: Es fällt schwer, sich mit ihm zu identifizieren. Er bleibt, trotz allem, ein fremder Held. Natürlich ist eine gewisse Fremdheit konstitutives Element des Helden an sich; wäre er wie wir, könnte er überhaupt ein Held sein? „Größe ist, was wir nicht sind“, heißt es bei

$15 \mathrm{Zu}$ heroischen Qualitäten siehe Achim Aurnhammer und Manfred Pfister: Vorwort. In: Achim Aurnhammer und Manfred Pfister (Hg.): Heroen und Heroisierungen in der Renaissance (Wolfenbütteler Abhandlungen zur Renaissanceforschung; 28). Wiesbaden 2013, 7-12, hier 11. Siehe auch von den Hoff: Helden - Heroisierungen - Heroismen (Anm. 2), 8, und Ronald G. Asch: The Hero in the Early Modern Period and Beyond: An Elusive Cultural Construct and an Indispensable Focus of Social Identity? In: helden. heroes. héros. Special Issue 1, 2014, 5-14, hier 6, DOI 10.6094/helden.heroes.heros./2014/QM/02. Für die Echostruktur als Mittel der Verehrung siehe Hertel: Bragging Turks and Winning Words (Anm. 8), 256-258.

16 von den Hoff: Helden - Heroisierungen - Heroismen (Anm. 2), 11.

17 Greenblatt: Marlowe and Renaissance Self-Fashioning (Anm. 1), 207-229. 
Jakob Burckhardt. ${ }^{18}$ Vom Helden wird verlangt, dass er sich über das Gewöhnliche hinwegsetzt. ${ }^{19}$

Gilt das für alle Helden, so sind die Fremdheit und die Lust an der Transgression in Marlowes Tamburlaine jedoch bis ins Extreme gesteigert. Sie scheinen nachgerade seinen Wesenskern auszumachen. Tamburlaine ist damit typisch für Marlowes Protagonisten, denen oft eine unüberbrückbare Fremdheit eignet, eine Fremdheit, die sie unterscheidet etwa von Shakespeares Helden. Diese mögen uns fremd sein durch ihre historische Distanz, ihren sozialen Status, ihre geografische Verankerung oder ihren kühlen Machiavellismus. Und doch: Shakespeares Helden bleiben zugänglich. ${ }^{20}$ Wenn Lear als eitler Alter aus blöder Selbstverliebtheit seine Töchter zu einem Wettstreit der Liebe antreten lässt oder Heinrich V., allem heroischen Gebaren zum Trotz, von Selbstzweifeln geplagt wird, aus denen er sich nur rhetorisch befreien kann; wenn sich in Othello fatale Leidenschaft Bahn bricht, dann können wir mitfühlen. Solche Momente, in denen Helden menschliche Züge zeigen, finden sich bei Marlowe selten. Sein Jude Barabas bleibt - anders als Shakespeares Shylock - bei allem Unrecht, das ihm widerfährt, durch und durch unsympathisch und böse. Auch Faustus in seinem blinden Hochmut bleibt fremd. Anders als Shakespeares Helden sehen wir sie von außen - wir schauen auf sie, nicht in sie hinein oder gar mit ihren Augen. ${ }^{21}$

Für Tamburlaine gilt das in besonderem Maße. Auch wenn seine ikonoklastische Gewalt protestantische Fantasien bedienen mag, auch wenn sein aggressives Auftreten bei der unter weiblicher Regentschaft frustrierten Elite auf fruchtbaren Boden fallen mag, auch wenn seine imperialen Eroberungen englische Ambitionen einzulösen versprechen - letztlich bleibt Tamburlaine doch fremd. Wir verstehen ihn nicht, und Marlowe unternimmt keinen Versuch, ihn verstehbar zu machen. Selbst wenn Tamburlaine agiert, wie es die Elisabethaner vielleicht gerne täten - er ist letztlich nicht wie sie. Er ist, vielleicht sogar im Sinne Freuds, unheimlich; in ihm wird Vertrautes, werden eigene Ambitionen, fremd, verfremdet. ${ }^{22}$ Diese Ambivalenz ist zentral für Tamburlaine. Mag er auch englischen Wunschvorstellungen entspringen, so bleibt er doch charakterisiert durch eine Fremdheit, die weit über jene hinausgeht, die für Helden konstitutiv ist.

Wozu aber diese übersteigerte Distanz? Ich denke, sie verweist auf zweierlei. Zum einen kann nur ein fremder Tamburlaine als Figur fungieren, die eigene englische Ambitionen zu heroisieren vermag. Das Selbst taugt bekanntlich nicht zum Helden, und wenn Marlowe daran gelegen ist, englische imperiale Ambitionen heroisch zu überhöhen, dann benötigt er die Figur eines Anderen wie jene Tambur-

18 Zitiert in Manfred Pfister: Zur Einführung: Heldenfigurationen der Renaissance. In: Achim Aurnhammer und Manfred Pfister (Hg.): Heroen und Heroisierungen in der Renaissance (Wolfenbütteler Abhandlungen zur Renaissanceforschung; 28). Wiesbaden 2013, 13-26, hier 14. Asch: The Hero in the Early Modern Period and Beyond (Anm. 15), 6.

20 Siehe auch Stevie Simkin: Marlowe. The Plays. Houndmills [u.a.] 2001, 48.

21 Ebd., 48-49.

22 Sigmund Freud: Das Unheimliche. Aufsätze zur Literatur. Hamburg 1963. 
laines. Zum anderen verkörpert Tamburlaine nicht alleine Machtfantasien, er schützt das Publikum zugleich vor ihnen. Die Fremdheit von Marlowes Protagonisten bewahrt das Publikum davor, die Grausamkeit akzeptieren zu müssen, die mit imperialen Ambitionen einhergeht. Indem Marlowe Tamburlaine als fremden Helden entwirft, ermöglicht er seinem Publikum, sich von den Kosten solcher Großmachtfantasien - der Grausamkeit gegen andere, der Gewalt als Mittel des Aufstiegs, dem Umstürzlerischen, dem Größenwahn - zu distanzieren: So wie Tamburlaine sind wir eben nicht.

So ist die Ambivalenz Tamburlaines diejenige elisabethanischer Ambitionen: Er fungiert zugleich als Verkörperung englischer Träume vom Empire und als Objekt eines Exorzismus, in dem die emotionalen, humanen und sozialen Kosten dieses Strebens ausgetrieben werden, indem sie auf diese Figur radikaler Fremdheit projiziert werden. Es ist kein Zufall, dass Marlowe Tamburlaine nach heroischem Muster entwirft: Für diese doppelte Dynamik der Selbstkonstruktion zwischen Teilhabe und Negierung eignet sich so gut wie keine zweite die Figur des fremden Helden.

\section{Abbildungsnacbreise}

Abb. 1 und 2: (C) Huntington Library, San Marino. 